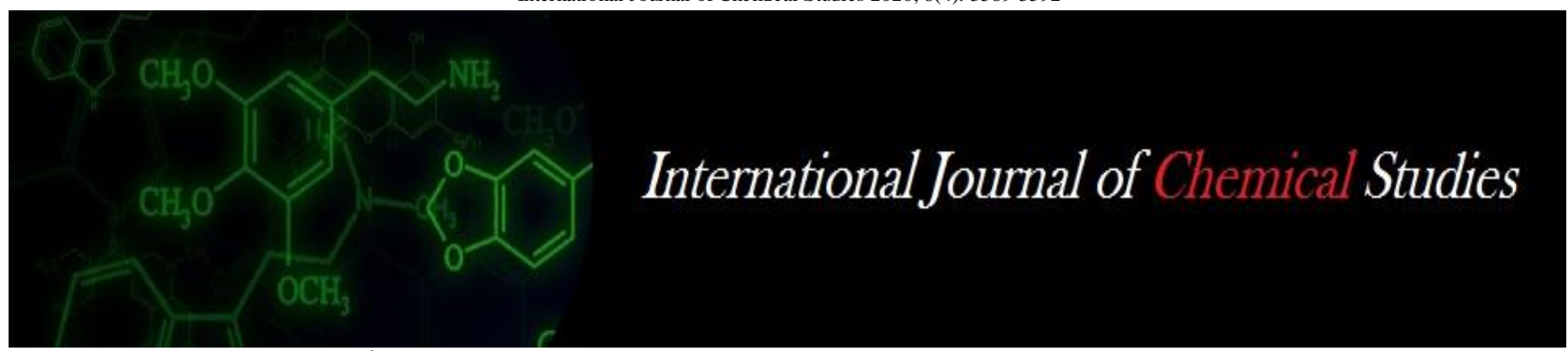

P-ISSN: 2349-8528

E-ISSN: 2321-4902

www.chemijournal.com

IJCS 2020; 8(4): 3589-3592

(C) 2020 IJCS

Received: 20-04-2020

Accepted: 22-05-2020

\section{RS Marbate}

P.G. Students, Agronomy

Section, College of Agriculture,

Nagpur, Maharashtra, India

\section{AL Uparkar}

P.G. Students, Agronomy

Section, College of Agriculture,

Nagpur, Maharashtra, India

\section{RJ Choudhari}

P.G. Student, Agricultural

Pathology Section, Post

Graduate Institute, Dr. P. D. K.

V., Akola, Maharashtra, India

\section{Dr. PC Pagar}

Assistant Professor of

Agronomy, Agronomy Section,

College of Agriculture

(Dr. P.D.K.V., Akola),

Nagpur, Maharashtra, India
Corresponding Author: RS Marbate

P.G. Students, Agronomy

Section, College of Agriculture,

Nagpur, Maharashtra, India

\section{Yield and economics of linseed as influenced by different land configuration and irrigation levels}

\author{
RS Marbate, AL Uparkar, RJ Choudhari and Dr. PC Pagar
}

DOI: $\underline{\text { https://doi.org/10.22271/chemi.2020.v8.i4as.10207 }}$

\begin{abstract}
An investigation was undertaken at College of Agriculture, Nagpur to study the effect of land configuration and irrigation levels on growth, yield attributes and yield of linseed during rabi season of 2014-2015 in split plot design with twelve treatment combinations consisting of four land configurations viz., $\mathrm{L}_{1}$ (Flat bed), $\mathrm{L}_{2}$ (Ridges and furrow), $\mathrm{L}_{3}$ (Opening of furrow after two rows) and $\mathrm{L}_{4}$ (Broad bed furrow) and three irrigation levels viz., I1- One irrigation at flowering (40-45 DAS), I2- Two irrigations, one at flowering (40-45 DAS) and second at capsule formation (65-70 DAS) and $\mathrm{I}_{3}$ - Three irrigations, one at vegetative (20-25 DAS), second at flowering (40-45 DAS) and third at capsule formation (65-70 DAS) replicated three times. Linseed variety PKV NL-260 was used as a test crop. The soil was clayey in texture with $\mathrm{p}^{\mathrm{H}} 7.8$ indicating slightly alkaline in reaction. Results showed that application of land configuration treatments significantly increased yield contributing characters such as number of capsule plant $^{-1}$, number of seed capsule ${ }^{-1}$, seed yield plant ${ }^{-1}(\mathrm{~g})$, seed and straw yield $\left(\mathrm{kg} \mathrm{ha}^{-1}\right)$. Highest values of all the yield contributing characters, seed and straw yield were recorded in land configuration treatment of broad bed furrow (BBF) but at par with sowing on ridges and furrow. Sowing of linseed on broad bed furrow (BBF) significantly increased GMR, NMR and achieved higher value of B:C ratio (4.37) than other treatments. Results further revealed that, application of three irrigations, one at vegetative stage, second at flowering and third at capsule formation recorded significantly higher values of yield attributing parameters like number of capsule plant ${ }^{-1}$, number of seed capsule ${ }^{-1}$, seed yield plant $^{-1}(\mathrm{~g})$, seed and straw yield $\mathrm{kg} \mathrm{ha}^{-1}$ over treatment of one irrigation at flowering and was at par with two irrigations, one at flowering and second at capsule formation. It also recorded maximum values of gross monetary return and net monetary returns. Interaction effect of land configuration and irrigation levels were found to be non significant in respect of yield parameters as well as seed yield $\mathrm{kg} \mathrm{ha}^{-1}$.
\end{abstract}

Keywords: Yield, land configuration, irrigation levels, yield attributes

\section{Introduction}

Linseed (Linum usitatissimum L.) is an important oilseed crop of central India, locally known as jawas or alsi. It has been grown from ancient time for flax (fiber) and for seed purpose which is rich in oil. Linseed contains high level of lignan and Omega-3 fatty acid possesses anti cancer properties and studies found reduced growth in specific types of tumors. Initial studies suggest benefit individual with certain types of breast and prostate cancer. Linseed is unique among oilseeds as it has high content of Omega-3 fatty acid, alpha linolenic acid (ALA). Linseed contains 35 to $45 \%$ oil with ALA making up about $57 \%$ of the total fatty acids. Omega-3 fatty acids lower levels of triglycerides in blood, thereby reducing heart disease, and also shows promising battle against inflammatory diseases such as rheumatoid arthritis. Linolenic acid (LA), an Omega-6 essential fatty acid is also found in linseed. In India it is grown over an area 468.0 thousand ha which produce about 1.41 lakh tonnes and its cultivation is mostly confined to Madhya Pradesh, Uttar Pradesh, Maharashtra, Bihar and West Bengal. Madhya Pradesh rank first in both area and production among linseed growing states of India. Since, area under linseed is decreased now a day due to low yield hence production technology suitable to its high production needs to be perfected. Increase in crop production can be realized by either extending total area under this crop or by enhancing crop productivity. To ensure high crop productivity, adoption of improved agronomic techniques is essential. Most of the studies indicate that increase in yield is mainly associated with land configuration and irrigation management method. Resorting sowing on land configuration like broad bed and furrow (BBF), ridges and furrow and provision of furrow at regular intervals 
and reduced tillage are known to help linseed crop during water stress. The proper land configuration is known for increasing moisture intake and resultant yield. The broad bed and furrow acts as drains in high rainfall region and also help in providing more opportunity for in situ soil water conservation. Nalawade and More (1993) reported that, BBF give more pod yield than furrow in every row, furrow after two rows and flat beds. The BBF, NBF, furrow after two rows gave pod yield of $1.33,1.25,1.11 \mathrm{t} \mathrm{ha}^{-1}$, respectively. Excess irrigation causes water logging condition because heavy soils of Vidarbha are poor in drainage. This ultimately affects crop growth and further crop yield. Hence judicious uses of irrigation water become prime importance. Ram Pyare et al. (2005) ${ }^{[10]}$ reported that irrigation at flowering and capsule formation stage enhances grain yield to $4.33 \mathrm{q} \mathrm{ha}^{-1}$ than no irrigation. Therefore, timely irrigation is most important to get high yield from linseed crop. Yenpreddiwar et al. (2007) ${ }^{\text {[17] }}$ reported that, irrigation at flowering and capsule filling stages recorded highest yield of $1182 \mathrm{~kg} \mathrm{ha}^{-1}$ than irrigation at flowering stage and no irrigation. Deep black cotton soil having high water holding capacity and stickiness in Nagpur region of Maharashtra state limit the linseed cultivation due to poor drainage. To protect the crop from this hazard and to provide better soil condition for healthy, luxurious proliferation of roots and good response to fertilizer application suitable the present investigation was planned to find out an efficient land configuration method and an optimum irrigation level at which linseed gives maximum growth and seed yield.

\section{Materials and Methods}

A field experiment was conducted at Agronomy farm, College of Agriculture, Nagpur during rabi season of 20142015 in split plot design with twelve treatment combinations consisting of four land configurations viz., $\mathrm{L}_{1}$ (Flat bed), $\mathrm{L}_{2}$ (Ridges and furrow), $\mathrm{L}_{3}$ (Opening of furrow after two rows) and $\mathrm{L}_{4}$ (Broad bed furrow) as main plot treatments and three irrigation levels viz., $\mathrm{I}_{1 \text { - }}$ One irrigation at flowering (40-45 DAS), I $\mathrm{I}_{2}$ Two irrigations, one at flowering (40-45 DAS) and second at capsule formation (65-70 DAS) and $\mathrm{I}_{3-}$ Three irrigations, one at vegetative (20-25 DAS), second at flowering (40-45 DAS) and third at capsule formation (65-70 DAS) as sub plot treatments replicated three times. The soil of experimental plot was medium in available nitrogen (208.94 $\left.\mathrm{kg} \mathrm{ha}^{-1}\right)$, low in available phosphorus $\left(17.14 \mathrm{~kg} \mathrm{ha}^{-1}\right)$, medium in organic carbon $(0.57 \%)$ and very high in available potash (350.42 $\mathrm{kg} \mathrm{ha}^{-1}$ ) as regards to fertility status and slightly alkaline in reaction ( $\mathrm{pH}$ 7.8). The soil of the experimental field was clayey in texture. The crop variety PKV NL-260 was used with row to row spacing of $45 \mathrm{~cm}$. Gross plot size was $4.05 \mathrm{~m} \times 4.2 \mathrm{~m}$ and net plot size was $3.15 \mathrm{~m} \times 3.8 \mathrm{~m}$. The distance between two replications was $1.50 \mathrm{~m}$ and $1 \mathrm{~m}$ between two plots. Full dose of phosphorus and half dose of nitrogen were applied at sowing and remaining half dose of $\mathrm{N}$ was applied at $30 \mathrm{DAS}$.

At the time of harvesting, number of capsules plant ${ }^{-1}$, number of seeds capsule ${ }^{-1}$, seed yield plant $^{-1}(\mathrm{~g})$ test weight $(\mathrm{g})$, seed yield $\left(\mathrm{kg} \mathrm{ha}^{-1}\right)$ and straw yield $\left(\mathrm{kg} \mathrm{ha}^{-1}\right)$ were recorded. In order to represent the plot, five plants of linseed from each net plot were selected randomly for various biometric observations on post harvest studies. The selected five plants were labeled and all biometric observations were recorded properly on them.

\section{Results and Discussion}

Effect on yield attributes

The data pertaining to various yield attributes studied viz., number of capsules plant ${ }^{-1}$, number of seeds capsule ${ }^{-1}$, test weight $(\mathrm{g})$ and seed yield plant ${ }^{-1}(\mathrm{~g})$ as influenced by various treatments are presented in table 1.

\section{Effect of land configuration}

Number of capsules plant ${ }^{-1}$, number of seeds capsule ${ }^{-1}$ and seed yield plant ${ }^{-1}(\mathrm{~g})$ were significantly influenced due to land configuration treatments. Broad bed furrow $\left(\mathrm{L}_{4}\right)$ recorded significantly more number of capsules plant ${ }^{-1}$ (46.03) over flat bed $\left(\mathrm{L}_{1}\right)$ and furrow after two rows $\left(\mathrm{L}_{3}\right)$ but was at par with treatment $\left(\mathrm{L}_{2}\right)$ ridges and furrows (43.13). These findings are in close accordance with Jat et al. (2012), Meena et al. (2014), Lakhera (2008) ${ }^{[5]}$, Jaiswal (2014) ${ }^{[3]}$, Kantwa et al. (2005) ${ }^{[4]}$ and Rathore et al. (2010).

\section{Effect of Irrigation levels}

Irrigation treatments had significant influence on the number of capsules plant ${ }^{-1}$, number of seeds capsule ${ }^{-1}$ and seed yield plant $^{-1}(\mathrm{~g})$ with every irrigation. Treatment of three irrigations $\left(\mathrm{I}_{3}\right)$ one at vegetative stage, second at flowering and third at capsule formation recorded significantly more number of capsules plant $^{-1}$ (46.43), number of seeds capsule ${ }^{-1}$ (7.30) and seed yield plant ${ }^{-1}(\mathrm{~g})$ (2.46) over $\left(\mathrm{I}_{1}\right)$ one irrigation at flowering and was at par with two irrigations $\left(\mathrm{I}_{2}\right)$ one at flowering and second at capsule formation. Similar results were also reported by Yenpreddiwar (2006) ${ }^{[16]}$, Nagdive et al. (2007) ${ }^{[6]}$, Gabaiana et al. (2005) ${ }^{[2]}$ and Patil et al. (2011) ${ }^{[7]}$. Land configuration and irrigation levels treatments did not show any significant influence on the test weight of linseed.

\section{Interaction effect}

Interaction effects in respect of number of capsules plant ${ }^{-1}$, number of seeds capsule ${ }^{-1}$, test weight $(\mathrm{g})$ and seed yield plant $^{-1}(\mathrm{~g})$ were found non-significant.

\section{Effect on yield}

Data regarding mean seed yield $\left(\mathrm{q} \mathrm{ha}^{-1}\right)$ and straw yield ( $\mathrm{q}$ ha $\left.{ }^{1}\right)$ as influenced by different treatments are presented in table 1.

\section{Effect of Land configuration}

Seed yield $\mathrm{ha}^{-1}$ and straw yield $\left(\mathrm{q} \mathrm{ha} \mathrm{h}^{-1}\right)$ were significantly influenced due to various land configuration treatments. The land configuration treatment of BBF being at par with ridges and furrows showed significant increase in seed yield $\left(\mathrm{q} \mathrm{ha} \mathrm{h}^{-1}\right)$ and straw yield $\left(\mathrm{q} \mathrm{ha}^{-1}\right)$ over flat bed and furrow after two rows. It is a well known fact that, land configuration treatments helps in moisture conservation and providing good drainages which might be the reasons in producing more yields in these treatments. Similar effects of modified land configuration have also been reported by Kantwa et al. (2005) ${ }^{[4]}$ and Paul (2014) ${ }^{[9]}$.

\section{Effect of Irrigation levels}

Seed yield $\mathrm{ha}^{-1}$ and straw yield $\left(\mathrm{q} \mathrm{ha}{ }^{-1}\right)$ were significantly influenced due to irrigation levels. Seed yield was maximum in application of $\left(\mathrm{I}_{3}\right)$ three irrigations $\left(13.64 \mathrm{q} \mathrm{ha}^{-1}\right)$, one at vegetative stage, second at flowering and third at capsule formation which were at par with $\left(\mathrm{I}_{2}\right)$ two irrigations $(13.0 \mathrm{q}$ $\mathrm{ha}^{-1}$ ), one a flowering and second at capsule formation and significantly superior over $\left(\mathrm{I}_{1}\right)$ one irrigation at flowering. 
This clearly indicated availability of moisture increased vigour and growth of crop which helped in improving the yield components and consequently yield. These findings are in close accordance with Yenpreddiwar et al. (2007) ${ }^{[17]}$, Jaiswal (2014) ${ }^{[3]}$ and Ram-Pyare et al. (2005) ${ }^{[10]}$.

\section{Interaction effect}

Interaction effect was found to be non significant.

\section{Effect on economic studies}

Data presented in Table 1 indicated the gross monetary returns (Rs. ha $\left.{ }^{-1}\right)$, net monetary returns $\left(\mathrm{Rs} . \mathrm{ha}^{-1}\right)$ and $\mathrm{B}: \mathrm{C}$ ratio as influenced by various treatments. The mean gross monetary returns and net monetary returns found to be Rs. $63729 \mathrm{ha}^{-1}$ and Rs. $47124 \mathrm{ha}^{-1}$.

\section{Effect of Land configuration}

It could be seen from the data prescribed in Table 1 that, gross monetary returns and net monetary returns were significantly highest in treatment BBF (Rs. 69872 ha $^{-1}$ ) and (Rs. $53902 \mathrm{ha}^{-1}$ ) respectively over flat bed and furrow after two rows which was at par with the treatment of ridges and furrow. These findings are in close accordance with Patil (2005) ${ }^{[8]}$ and Patil et al. (2011) ${ }^{[7]}$. Treatment of BBF gave highest benefit cost ratio (4.37) followed by treatment of ridges and furrow (3.86) and furrow after two rows (3.82). The benefit cost ratio was lowest in flat bed (3.31).

\section{Effect of Irrigation levels}

The gross monetary returns and net monetary returns were significantly influenced due to various irrigation treatments. Treatment $\mathrm{I}_{3}$ (three irrigations, one at vegetative stage, second at flowering and third at capsule formation stage) recorded significantly higher gross monetary returns (Rs.68241 ha-1) and net monetary returns (Rs.51496 ha- ${ }^{-1}$ ) over one irrigation at flowering $\left(\mathrm{I}_{1}\right)$ was found at par with two irrigations, one at flowering and second at capsule formation $\left(\mathrm{I}_{2}\right)$. Similar results were reported by Sharma et al. (2005). Maximum B:C ratio of (4.07) was recorded with treatment $\left(\mathrm{I}_{3}\right)$ three irrigations, one at vegetative stage, second at flowering and third at capsule formation stage, followed by treatment $\left(\mathrm{I}_{2}\right)$ two irrigations, one at flowering and second at capsule formation (3.91). The $\mathrm{I}_{1}$ (one irrigation at flowering) treatment registered lowest $\mathrm{B}: \mathrm{C}$ ratio (3.51).

\section{Interaction}

Interaction effect was found to be non significant.

Table 1: Yield and Economics of Linseed As Influenced By Different Land Configuration and Irrigation Levels

\begin{tabular}{|c|c|c|c|c|c|c|c|c|c|}
\hline Treatments & \multicolumn{4}{|c|}{ Yield attributes } & \multicolumn{2}{|c|}{ Yield } & \multicolumn{3}{|c|}{ Economics } \\
\hline Land configuration & $\begin{array}{c}\text { Number of } \\
\text { capsules } \\
\text { Plant }^{-1}\end{array}$ & $\mid \begin{array}{c}\text { Number of } \\
\text { seeds capsule }^{-1}\end{array}$ & $\begin{array}{c}\text { Test } \\
\text { weight } \\
\text { (g) }\end{array}$ & $\begin{array}{l}\text { Seed yield } \\
\text { plant-1 (g) }\end{array}$ & $\begin{array}{c}\text { Seed Yield } \\
\left(\mathbf{q} \mathbf{h a}^{-1}\right)\end{array}$ & $\begin{array}{c}\text { Straw Yield } \\
\left(\mathbf{q} \mathbf{h a}^{-1}\right)\end{array}$ & $\begin{array}{c}\text { Gross } \\
\text { monetary } \\
\text { returns } \\
\left(\text { Rs. ha }{ }^{-1}\right) \\
\end{array}$ & $\begin{array}{c}\text { Net } \\
\text { monetary } \\
\text { returns } \\
\left(\text { Rs. ha }{ }^{-1}\right)\end{array}$ & \begin{tabular}{|} 
B:C \\
Ratio
\end{tabular} \\
\hline $\mathrm{L}_{1}$ - Flat bed & 39.74 & 6.77 & 7.51 & 1.99 & 11.18 & 13.92 & 55922 & 39052 & 3.31 \\
\hline L2- Ridges and furrow & 43.13 & 6.89 & 7.72 & 2.52 & 13.15 & 14.89 & 65772 & 48762 & 3.86 \\
\hline $\begin{array}{c}\text { L3- Furrow after two } \\
\text { rows }\end{array}$ & 41.01 & 6.59 & 7.67 & 2.26 & 12.67 & 14.02 & 63350 & 46780 & 3.82 \\
\hline $\mathrm{L}_{4}-\mathrm{BBF}$ & 46.03 & 7.46 & 7.81 & 2.60 & 13.97 & 17.15 & 69872 & 53902 & 4.37 \\
\hline $\mathrm{SE}(\mathrm{m}) \pm$ & 0.85 & 0.16 & 0.19 & 0.07 & 0.34 & 0.66 & 1730 & 1730 & - \\
\hline $\mathrm{C} \mathrm{D}$ at $5 \%$ & 2.96 & 0.58 & N.S. & 0.25 & 1.19 & 2.30 & 5987 & 5987 & - \\
\hline \multicolumn{10}{|c|}{ Irrigation levels } \\
\hline $\mathrm{I}_{1}$ - One irrigation & 38.86 & 6.34 & 7.43 & 2.26 & 11.58 & 13.24 & 57933 & 41468 & 3.51 \\
\hline $\mathrm{I}_{2}$ - Two irrigations & 42.14 & 7.13 & 7.74 & 2.30 & 13.00 & 15.54 & 65012 & 48407 & 3.91 \\
\hline $\mathrm{I}_{3}$ - Three irrigations & 46.43 & 7.30 & 7.82 & 2.46 & 13.64 & 17.00 & 68241 & 51496 & 4.07 \\
\hline $\mathrm{S} \mathrm{E}(\mathrm{m}) \pm$ & 1.54 & 0.26 & 0.15 & 0.05 & 0.22 & 0.50 & 1107 & 1107 & - \\
\hline $\mathrm{C} \mathrm{D}$ at $5 \%$ & 4.64 & 0.80 & N.S. & 0.16 & 0.66 & 1.50 & 3320 & 3320 & - \\
\hline \multicolumn{10}{|c|}{ Interaction } \\
\hline $\mathrm{SE}(\mathrm{m}) \pm$ & 3.09 & 0.53 & 0.31 & 0.11 & 0.44 & 1.00 & 2215 & 2215 & - \\
\hline $\mathrm{CD}$ at $5 \%$ & N.S. & N.S. & N.S. & N.S. & N.S. & N.S. & N.S. & N.S. & - \\
\hline
\end{tabular}

\section{Conclusion}

Sowing of linseed on broad bed furrow recorded maximum yield attributes, yield and economics of linseed though it was at par with sowing on ridges and furrow. Sowing on either broad bed furrow or ridges and furrow gave maximum gross monetary returns and net monetary return over flat bed. Similarly, B:C ratio (4.37) was highest with sowing of linseed on BBF. Three irrigations viz., one at vegetative stage, second at flowering and third at capsule formation recorded maximum yield attributes and yield of linseed. It gave maximum gross monetary returns, net monetary returns and $\mathrm{B}: \mathrm{C}$ ratio than one irrigation at flowering but at par with two irrigations, one at flowering and second at capsule formation. Combination of land configuration and irrigation levels was found to be non-significant.

It is apparent from the data that sowing of linseed either on $\mathrm{BBF}$ or ridges and furrow with three irrigations was found to give maximum seed yield and net returns.

\section{References}

1. Anonymous. District socio-economic Review, 2013-14. Directorate of economic and statistic, Government of Maharashtra, 2014.

2. Gabaiana C, Mckenzie BA, Hill GD. The influence of plant population, nitrogen and irrigation on yield and yield components of linseed. Agron-New-Zealand. 2005; 35:44-56.

3. Jaiswal SG. Effect of irrigation layout and irrigation levels on growth and yield of mustard. M.Sc. (Agri.) Thesis (unpub) Dr. P.D.K.V., Akola, 2014.

4. Kantwa SR, Ahlawat IPS, Gangaiach B. Effect of land configuration, post monsoon irrigation and phosphorus on performance of sole and inter cropped pigeonpea. Indian J Agron. 2005; 50(4):278-280.

5. Lakhera Vishnuprakash, Effect of land configuration and nutrient management on productivity of soybean (Glycine 
max). M.Sc. (Agri) Thesis (unpbu), Dr. P.D.K.V., Akola, 2008.

6. Nagdive SJ, Bhalerao PD, Dongarwar UR, Goud VV. Effect of irrigation and nutrient management on yield, quality and uptake of nutrients by mustard. J Soils and Crops. 2007; 17(1):128-132.

7. Patil DB, Mendhe SN, Kolte HS, Sathe HD. Effect of land configuration and irrigation management on yield attributes and economics of linseed. Journal of Soils and Crops. 2011; 21(1):86-89.

8. Patil MR. Influence of nutrient management and land layouts on growth and yield of soybean, M.Sc. Thesis (unpub) Dr. P.D.K.V., Akola, 2005.

9. Paul SA. Effect of land configuration and nutrient management on productivity of irrigated linseed. M.Sc. (Agri.) Thesis (unpub) Dr. P.D.K.V., Akola, 2014.

10. Ram-Pyare RPS, Kedar-Prasad, Yadav SL. Effect of second irrigation based on cumulative pan evaporation on yield. Farm-sci-J. 2005; 14(2):40-42.

11. Sharma G, Sutaliya R, Jawahar Singh, Sharma KP. Production potential and economic return of Mustard [Brassica juncea (L.)] and Linseed (Linum usitatissimum L.) intercropping system under irrigated condition CropResearch-Hisar. 2005; 30(3):483-485.

12. Sharma G, Sutaliya R, Prasad S, Sharma ML. Effect of $\mathrm{N}$-fertilizers and irrigation on productivity (growth, seed yield and active substances) of linseed. Iranian J of Agric. Sci. 2003; 32(1):53-64.

13. Tekale DD, Supekar SJ, Basteward TB, Kadam SP. Effect of ICRISAT and conventional cultivation method of groundnut under sprinkler irrigation. J Soils and Crops. 2001; 11(1):43-44.

14. Thosar VR, Ulemale RB, Jibhkate BM. Studies on yield response of linseed (Linum usitatissimum L.) to frequency of irrigation. Ann. Plant Physiol. 1990; 4(1):54-58.

15. Tiwari OK, Dash AC, Rajput RS, Khaddar VK. Production potential of soybean (Glycine max. L. Merrill) and physico-chemical properties of soil as influenced by city waste (Celrich), inorganic and biofertilizers J. of Soils and, 1994.

16. Yenpreddiwar MD. Effect of irrigation and moisture conservation practices on growth, yield and quality of linseed. M.Sc. Thesis submitted to Dr. P.D.K.V., Akola, 2006.

17. Yenprediwar MD, Nikam RR, Dange RB, Gaidhane SN. Water use studies in linseed as influenced by different irrigation levels and moisture conservation practices. J. of Soil and Crops. 2007; 17(1):176-177. 